\title{
The effects of early physiotherapy on biochemical parameters in major burn patients: A burn center's experience
}

\author{
ㄴ) Murat Ali Çınar, PT, Msc, ${ }^{1}$ ○ Kezban Bayramlar, PT, PhD., ${ }^{1} \odot$ Ahmet Erkılıç, M.D., ${ }^{2}$ \\ 당 Ali Güneş, M.D., ${ }^{2}$ 이 Yavuz Yakut, PT, PhD. ${ }^{1}$
}

\begin{abstract}
1'Department of Physical Therapy and Rehabilitation, Hasan Kalyoncu University Faculty of Health Sciences, Gaziantep-Turkey ${ }^{2}$ Department of General Surgery, 25 Aralık State Hospital, Burn Center, Gaziantep-Turkey
\end{abstract}

\begin{abstract}
BACKGROUND: This study sets out to investigate the effects of early physiotherapy on biochemical parameters in major burn patients.

METHODS: Ten women (50\%) and 10 men (50\%) aged $21-47$ years old were included in this study. Participants were divided into two groups: the first group was the treatment group and the second group was the control group. In the treatment group, patients were admitted to the physiotherapy programme from the first day they have been hospitalised, in addition to their routine treatment (e.g. medical, surgery), for four days per week. The physiotherapy programme consisted of parameters, such as early mobilisation and ambulatory training, chest physiotherapy, and both active and passive normal joint movement exercises. The days of treatment were determined as of Tuesday, Wednesday, Thursday and Friday. Patients could not be treated on a Monday because that was surgery day. The control group consisted of patients who could not receive physiotherapy due to various reasons. All patients included in this study were evaluated weekly for six weeks after admission to the hospital. Parameters, such as demographic information, characteristics of burn injury, C-reactive protein, fibronectin, transferrin and prealbumin, were evaluated.
\end{abstract}

RESULTS: When the results obtained in this study were considered, there was a significant difference in favour of the treatment group for all biochemical parameters $(p<0.05)$. From the second week, a significant increase was observed in prealbumin values in the treatment group $(p<0.05)$. A significant increase was observed in fibronectin after the fourth week $(p<0.05)$.

CONCLUSION: We believe that early physiotherapy should be included in the treatment in major burns. Early physiotherapy may reduce the effects of hypermetabolic response after major burns. There is a need for multi-centered and broader studies.

Keywords: Biochemical parameters; early physiotherapy; fibronectin; major burns; prealbumin.

\section{INTRODUCTION}

Burn injury is one of the longest traumas based on the duration of both hospitalisation and rehabilitation periods and its role in causing severe mortality and morbidity. ${ }^{[1]}$ The American Burn Association (ABA) defines major burns as second degree burns with a total body surface area (TBSA) greater than $25 \%$ in adults, second degree burns with TBSA greater than $20 \%$ in children and all third-degree burns with TBSA above $10 \%$. All burns, including hands, face, eyes, ears, feet, perineal burns, inhalation burns, electrical burns and fractures, fall into the major burn category. ${ }^{[2]}$
Lipolysis, proteolysis, glycolysis, and high fever, as well as many hyperdynamic and hypermetabolic responses, are seen in burn patients who have greater than $20 \%$ of the TBSA affected. These hypermetabolic responses seen in burn patients lead to decreased lean muscle mass, delayed wound healing weakened the immune system and premature mortality. ${ }^{[3]}$ In the first 24 hours after major burns, fluid accumulation in the interstitial space occurs due to increased vascular permeability, whereas decreased intravascular volume affects tissue perfusion if no intervention ensues. Cardiac output is reduced, all systems, especially the gastrointestinal and renal systems, are affected. Because of burn injury, electrolytes in

Cite this article as: Çınar MA, Bayramlar K, Erkılıç A, Güneş A, Yakut Y. The effects of early physiotherapy on biochemical parameters in major burn patients: A burn center's experience. Ulus Travma Acil Cerrahi Derg 2019;25:461-466.

Address for correspondence: Murat Ali Çınar, M.D.

Hasan Kalyoncu Üniversitesi, Havaalanı Yolu Üzeri 8. km., Şahinbey, 27000 Gaziantep, Turkey

Tel: +90 342 - 2118080 E-mail: muratali.cinar@hku.edu.tr

Ulus Travma Acil Cerrahi Derg 2019;25(5):46I-466 DOI: 10.5505/tjtes.2018.05950 Submitted: 10.06.2018 Accepted: 25.12.2018 Online: 20.08.2019

Copyright 2019 Turkish Association of Trauma and Emergency Surgery 
the body are also affected and can lead to cell death. ${ }^{[4]}$ The role of rehabilitation in burn treatment is becoming increasingly important, especially for major burn patients who need long-term rehabilitation, a process that includes both acute and post-discharge periods. ${ }^{[5]}$ Rehabilitation should begin from the first day when the patient lies in the hospital.

In the literature, various researchers investigated the potential effects of physiotherapy on blood values. For example, Aguiar et al. ${ }^{[6]}$ reported that the exercise therapy protocol could be a strategy for reducing IL-6 levels patients with OA of the knee. Kisacik et al. ${ }^{[7]}$ concluded that e multidimensional exercise program should be taken into consideration for ankylosing spondylitis patients due to its positive effects on level of biochemical parameters, such as ESR, CRP and IL6. In the other research, Ruiz-Castilla et al. ${ }^{[8]}$ stated that biomarkers might be a useful tool to guide burn treatments and may also explain why some treatments succeed or fail in improving outcomes. In the same article, they emphasised that an investigation into biomarkers in severe burn patients is a key feature of translational medicine in this area of knowledge. However, few studies examined the effects of physiotherapy on biochemical parameters in burn patients.

To contribute to the literature, the present study aims to investigate the effects of early physiotherapy on biochemical parameters in major burn patients.

\section{MATERIALS AND METHODS}

This study was carried out in 25 Aralık State Hospital Burn Center and Hasan Kalyoncu University, Faculty of Health Sciences, Department of Physiotherapy and Rehabilitation between October 2016 and April 2017.

20 major burn patients ( 10 women, 10 men) were included in this study. The inclusion criteria were:

- Age $\geq 18$ years;

- Major burn injury (according to ABA);

- Conscious patients. Patients with inhalation injury, various chronic disorders, organ dysfunctions, infection in the burn wound or the bloodstream and sepsis were all excluded from this study.

Nutrient types and diets were the same in all groups. All patients received similar standard medical care and treatment from the time of emergency admission and acute care of the burn injury until the time of discharge. In addition, types and numbers of clinical interventions, such as surgical debridement and grafting, were similar in all groups. All patients who were included in this study were assessed for six weeks from the first day of hospitalisation and taken to the treatment programme. C-reactive protein (CRP), fibronectin, transferrin and prealbumin biochemical values of patients in all groups were recorded weekly from the first day of hospitalisation. Measurements of biochemical parameters were performed in
Table I. Physiotherapy protocol

\begin{tabular}{ll}
\hline $\begin{array}{l}\text { Parameters of PT } \\
\text { protocol }\end{array}$ & $\begin{array}{l}\text { Early stage burn } \\
\text { PT protocol }\end{array}$ \\
\hline $\begin{array}{l}\text { Duration of PT } \\
\text { Times per day }\end{array}$ & $45-60$ min \\
How many times a week & 2 \\
PT on admission & 4 \\
PT after grafting & From the first day \\
Chest physiotherapy & Third day of grafting \\
& Respiratory exercises according \\
Exercise therapy & to the state of affection \\
& Active and passive ROM \\
& exercises according to the \\
Training of mobilization & patient's condition \\
and ambulation & From the first day \\
Appropriate anti- & \\
contracture positioning & From the first day \\
\hline
\end{tabular}

PT: Physiotherapy; ROM: Range-of-motion.

Table 2. Times of treatment

\begin{tabular}{lcc}
\hline Days of treatment & Morning & Afternoon \\
\hline $\begin{array}{l}\text { Monday } \\
\text { Tuesday }\end{array}$ & $\begin{array}{c}\text { Operation } \\
\text { Physiotherapy }\end{array}$ & Operation \\
Wednesday & Wound dressing & Physiotherapy \\
$\begin{array}{l}\text { Thursday } \\
\text { Friday }\end{array}$ & Physiotherapy & \\
Saturday & Wound dressing & Physiotherapy \\
Sunday & Wound dressing & \\
\hline
\end{tabular}

25 Aralık State Hospital Laboratories. Both initial and weekly values of the measured parameters were recorded.

Patients in the treatment group have been received to the physiotherapy programme on the four times a week schedule, in addition to their routine treatment (such as medical treatment and surgery) from the first day of their stay in the hospital. Details of the physiotherapy programme are shown in Table I. The control group consisted of patients who could not receive physiotherapy due to various reasons. For example, some Syrian patients did not want to receive physiotherapy due to communication problems. Despite the interpreter, they refused to communicate. Thus, they could not have physiotherapy. Treatment days were determined as of Tuesday, Wednesday, Thursday and Friday (Table 2).

\section{Ethics Approval and Consent to Participate}

Ethical approval was obtained from the Hasan Kalyoncu 
University, Faculty of Health Sciences Ethics Committee. Patients were informed of the nature of this study, and consent form was signed. Patients were made aware of their rights to withdrawn from this research at any time.

\section{Statistical Analysis}

The statistical software of Statistical Product and Service Solutions 22.0 (SPSS) for Windows was used for analysis. A value of $p<0.05$ was considered statistically significant. In the study, which was formed by groups of 10 people for six weeks, the power of this study was $91 \%$, according to the prealbumin value. ${ }^{[9]}$

Variables which were determined by numerical measurements were expressed as arithmetic averages and standard deviations (mean $\pm \mathrm{SD}$ ) for descriptive analyses. A Kolmogorov Smirnov test was used to investigate the normal distribution of biochemical parameters in our study. A t-test was used because the data showed a normal distribution.

\section{RESULTS}

A total of 20 patients, 10 females and 10 males, participated in this study. The ages of patients ranged from 21 to 47 years old. When burn injuries of patients were evaluated; 19 (95\%) were found to have flame burns, and I (5\%) were found to have electrical burns. Also, it was observed that both the treatment group and the control group had burn injury percentages varying between 30 and 55 (Table 3).

When the CRP values of the groups were examined; CRP values were found to be above normal reference values in both groups. When the groups were compared with each other, there was a significant decrease in the CRP value only during the last week in the treatment group compared with the control group $(p<0.05)$ (Table 4).

Initial and weekly measurements of fibronectin values were evaluated in both groups. Fibronectin values in the control group were below reference values for all weeks. In the treatment group, fibronectin values were below reference values only at one and two weeks. When the groups were compared, there was a difference starting in the fourth week in favour of the treatment group $(p<0.05)($ Table 5$)$.

When initial and weekly measurements of transferrin values were evaluated in both groups, it was determined that transferrin values were observed below reference values in both groups for all weeks. When the groups were compared, it was observed that there was a significant difference in favour of the treatment group from the first week $(p<0.05)$ (Table 6).

Initial and weekly measurements of prealbumin values were evaluated in both groups. It was determined that transferrin values were observed below reference values in both groups
Table 3. Properties of burn patients

\begin{tabular}{|c|c|c|}
\hline & Treatment group & Control group \\
\hline Age, years (Mean $\pm S D)$ & $30.1 \pm 8.3$ & $33.3 \pm 10.6$ \\
\hline (Min-Max) & $21-47$ & $20-47$ \\
\hline \multicolumn{3}{|l|}{ Sex, n (\%) } \\
\hline Female & $3(30)$ & $7(70)$ \\
\hline Erkek & $7(70)$ & $3(30)$ \\
\hline Percentage of burn, & $37.5 \pm 7.9$ & $41.5 \pm 9.5$ \\
\hline$($ Mean $\pm S D)($ Min-Max) & $30-55$ & $30-55$ \\
\hline \multicolumn{3}{|l|}{ Type of burn n(\%) } \\
\hline Flame & $10(100)$ & $9(90)$ \\
\hline Electrical & & I (I0) \\
\hline
\end{tabular}

SD: Standard deviation; Min: Minimum; Max: Maximum.

Table 4. CRP values

\begin{tabular}{|c|c|c|c|c|}
\hline \multirow{2}{*}{$\begin{array}{l}\text { CRP } \\
\text { Reference range } \\
(0-0.5 \mathrm{mg} / \mathrm{dL})\end{array}$} & $\begin{array}{c}\text { Treatment } \\
\text { group }\end{array}$ & $\begin{array}{l}\text { Control } \\
\text { group }\end{array}$ & $\mathbf{t}$ & $\mathbf{p}$ \\
\hline & Mean $\pm S D$ & Mean士SD & & \\
\hline First day & $12.57 \pm 8.16$ & $9.89 \pm 9.07$ & 0.694 & 0.496 \\
\hline Ist $^{\text {st }}$ week & $17.89 \pm 7.92$ & $25.19 \pm 10.63$ & -1.742 & 0.099 \\
\hline $2^{\text {nd }}$ week & $16.26 \pm 7.01$ & $16.37 \pm 5.23$ & -0.039 & 0.969 \\
\hline $3^{\text {rd }}$ week & $10.16 \pm 6.38$ & $|3.98 \pm 4.3|$ & -1.566 & 0.135 \\
\hline $4^{\text {th }}$ week & $9.29 \pm 4.61$ & $11.92 \pm 4.60$ & -1.278 & 0.217 \\
\hline $5^{\text {th }}$ week & $8.08 \pm 5.43$ & $12.46 \pm 6.20$ & -1.682 & 0.110 \\
\hline $6^{\text {th }}$ week & $4.94 \pm 3.22$ & $12.85 \pm 7.20$ & -3.169 & $0.005^{*}$ \\
\hline
\end{tabular}

"P<0.05. CRP: C-reactive protein; SD: Standard deviation.

Table 5. Fibronectin values

\begin{tabular}{|c|c|c|c|c|}
\hline \multirow{2}{*}{$\begin{array}{l}\text { Fibronectin } \\
\text { Reference range } \\
(25-40 \mathrm{mg} / \mathrm{dL})\end{array}$} & \multirow{2}{*}{$\begin{array}{c}\begin{array}{c}\text { Treatment } \\
\text { group }\end{array} \\
\text { Mean士SD }\end{array}$} & \multirow{2}{*}{$\begin{array}{c}\begin{array}{c}\text { Control } \\
\text { group }\end{array} \\
\text { Mean士SD }\end{array}$} & \multirow[t]{2}{*}{$\mathbf{t}$} & \multirow[t]{2}{*}{$\mathbf{p}$} \\
\hline & & & & \\
\hline First day & $30.05 \pm 7.14$ & $31.52 \pm 6.13$ & -0.494 & 0.627 \\
\hline I st week & $24.35 \pm 11.20$ & $22.10 \pm 11.06$ & 0.452 & 0.657 \\
\hline $2^{\text {nd }}$ week & $20.40 \pm 13.08$ & $19.25 \pm 9.06$ & 0.229 & 0.822 \\
\hline $3^{\text {rd }}$ week & $27.72 \pm 13.42$ & $19.60 \pm 9.15$ & 1.582 & 0.131 \\
\hline $4^{\text {th }}$ week & $39.44 \pm 10.10$ & $18.13 \pm 8.95$ & 4.993 & $<0.001^{*}$ \\
\hline $5^{\text {th }}$ week & $40.15 \pm 10.91$ & $16.74 \pm 9.52$ & 5.113 & $<0.001^{*}$ \\
\hline $6^{\text {th }}$ week & $40.33 \pm 10.66$ & $13.93 \pm 6.39$ & 6.714 & $<0.001^{*}$ \\
\hline
\end{tabular}

for all weeks. However, prealbumin values in the treatment group were found to be slightly below reference values from 
Table 6. Transferrin values

\begin{tabular}{|c|c|c|c|c|}
\hline \multirow{2}{*}{$\begin{array}{l}\text { Transferrin } \\
\text { Reference range } \\
\text { (202-364 mg/dL) }\end{array}$} & $\begin{array}{l}\text { Treatment } \\
\text { group }\end{array}$ & $\begin{array}{l}\text { Control } \\
\text { group }\end{array}$ & $\mathbf{t}$ & $\mathbf{p}$ \\
\hline & Mean $\pm S D$ & Mean $\pm S D$ & & \\
\hline First day & $109.07 \pm 29.68$ & $102.40 \pm 42.14$ & 0.409 & 0.687 \\
\hline I st week & $89.86 \pm 26.85$ & $66.70 \pm 13.69$ & 2.430 & $0.026^{*}$ \\
\hline $2^{\text {nd }}$ week & $110.43 \pm 28.95$ & $70.73 \pm 19.04$ & 3.623 & $0.002^{*}$ \\
\hline $3^{\text {rd }}$ week & $124.37 \pm 36.10$ & $71.32 \pm 21.85$ & 3.976 & $0.001^{*}$ \\
\hline $4^{\text {th }}$ week & $144.00 \pm 44.72$ & $60.13 \pm 13.50$ & 5.678 & $<0.001^{*}$ \\
\hline $5^{\text {th }}$ week & $160.18 \pm 3 \mid .74$ & $62.32 \pm 18.23$ & 8.455 & $<0.001^{*}$ \\
\hline $6^{\text {th }}$ week & $\mid 59.00 \pm 32.21$ & $55.88 \pm 15.10$ & 9.166 & $<0.00 I^{*}$ \\
\hline
\end{tabular}

Table 7. Prealbumin values

\begin{tabular}{|c|c|c|c|c|}
\hline \multirow{2}{*}{$\begin{array}{l}\text { Prealbumin } \\
\text { Reference range } \\
(0.2-0.4 \mathrm{~g} / \mathrm{dL})\end{array}$} & \multirow{2}{*}{$\begin{array}{c}\begin{array}{c}\text { Treatment } \\
\text { group }\end{array} \\
\text { Mean士SD }\end{array}$} & \multirow{2}{*}{$\begin{array}{c}\begin{array}{c}\text { Control } \\
\text { group }\end{array} \\
\text { Mean士SD }\end{array}$} & \multirow[t]{2}{*}{$\mathbf{t}$} & \multirow[t]{2}{*}{$\mathbf{p}$} \\
\hline & & & & \\
\hline First day & $0.10 \pm 0.05$ & $0.11 \pm 0.04$ & -0.540 & 0.596 \\
\hline I $^{\text {st }}$ week & $0.05 \pm 0.03$ & $0.03 \pm 0.01$ & 3.141 & $0.006^{*}$ \\
\hline $2^{\text {nd }}$ week & $0.07 \pm 0.03$ & $0.03 \pm 0.02$ & 3.417 & $0.003^{*}$ \\
\hline $3^{\text {rd }}$ week & $0.10 \pm 0.05$ & $0.04 \pm 0.01$ & 3.828 & $0.001^{*}$ \\
\hline $4^{\text {th }}$ week & $0.12 \pm 0.07$ & $0.03 \pm 0.01$ & 4.069 & $0.001^{*}$ \\
\hline $5^{\text {th }}$ week & $0.16 \pm 0.07$ & $0.05 \pm 0.05$ & 3.703 & $0.002^{*}$ \\
\hline $6^{\text {th }}$ week & $0.17 \pm 0.06$ & $0.05 \pm 0.03$ & 5.319 & $<0.001^{*}$ \\
\hline
\end{tabular}

"P<0.05. SD: Standard deviation.

the fifth week. When the groups were compared, it was observed that there was a significant difference in favour of the treatment group from the first week $(p<0.05)$ (Tablo 7).

\section{DISCUSSION}

In major burn patients, the organ which modulates the inflammatory response in the acute phase is the liver increased glycogenolysis, hyperglycaemia and insulin resistance underlie the inflammatory process. ${ }^{[10]}$ Also, CRP is used as a marker of the acute inflammatory condition. CRP is often used to monitor inflammation in burn patients during the acute phase. ${ }^{[1]}$

There are many studies in the literature about the effects of exercise on low-grade chronic inflammation. For example, Beavers et al. ${ }^{[12]}$ emphasised that walking exercises reduced the effects of chronic inflammation.

In this study, CRP values were observed to be approximately 30 times higher than the reference range for six weeks in both groups. Although CRP levels in the treatment group decreased significantly compared with the control group after the fifth week, it was observed that the reference interval was still 15 to 20 times higher than normal levels. Our findings suggest that physiotherapy in the acute phase alone is not sufficient to reduce CRP levels to normal levels. However, physiotherapy reduces the effects of the inflammatory response, which is due to the major burn in the acute phase.

Fibronectin is a marker that acts in all phases of wound healing and delays wound healing if it's deficient. In particular, fibronectin levels in the plasma provide information about wound healing in the acute phase. ${ }^{[13]}$ Studies in the literature demonstrate that fibronectin affects wound healing and also show the effects of both exercise and physiotherapy on wound healing. Especially in healthy individuals, walking exercises have been reported to be the most effective exercise in wound healing. ${ }^{[14,15]}$ Similarly, Çınar et al. ${ }^{[16]}$ stated that physiotherapy increases fibronectin levels in pilot studies in major burn patients.

In this study, fibronectin levels were observed at normal levels on the first day in both the treatment and control groups. It was quite remarkable that fibronectin values that had started to decrease at the beginning of the acute phase due to burn injury increased in the treatment group from the fourth week and reached normal values during the fifth week.

Major burn patients experience too many surgical operations during their treatment, which is grafting surgery. Therefore, patients need to devote a period to good wound healing. Thus, we believe that physiotherapy in the early period will positively affect wound healing of patients, may contribute to the success of graft operations and thus decrease the mortality of patients. In addition, delayed wound healing can lead to the formation of hypertrophic scarring in patients. ${ }^{[17]}$ Our findings suggest that early physiotherapy will shorten the wound healing period and prevent hypertrophic scar tissue formation.

Fibronectin values above the reference range may be indicative of poor wound healing or excessive scar tissue formation. [18] Also, to us it is not clinically meaningful that fibronectin values are slightly above the reference range in the treatment group in the sixth week.

Transferrin is a glycoprotein which is synthesised in the liver and can be affected by all the trauma that affects the liver. This biomarker, which controls iron concentrations of cells, also reduces inflammation and is directly linked to the immune system. Because transferrin is an acute-phase protein, it is characterised by severe reductions in the early period after major trauma. ${ }^{[19]}$ In the literature, to our knowledge, no studies related to the relationship between physiotherapy and transferrin has been found. Pouramir et al. ${ }^{[20]}$ reported that long-term exercise may drain iron deposits and cause 
serious problems analogous to the effects of exercise on iron ions in healthy subjects. In another study, it has been shown that long-term exercise in healthy individuals may have a negative effect on transferrin. ${ }^{[2]}$ Although in the literature it is argued whether transferrin and exercise may have a negative relationship, transferrin values of the patients in our treatment group were observed to be higher than of the patients in the control group from the first week. At the sixth week, our findings suggest that the highest level of transferrin in the treatment group is at a reasonable level clinically, even though it is below the reference range. Our findings suggest that physiotherapy is directly effective as the reason for the rise in transferrin. Our findings suggest that physiotherapy affects iron concentration indirectly by reducing the effects of the hypermetabolic response due to the burn. This indirect reduction in the effects of the hypermetabolic response has a positive impact on transferrin levels. In particular, the suppression of the immune system affects the transferrin value negatively. Iron deposits decrease due to inflammation and impairment of liver function in major burn patients. Our findings suggest that physiotherapy may have increased the level of transferrin because of both the reduction of inflammation and the positive effects on liver function. Thus, physiotherapy is necessary in addition to nutrition and medical treatment in the acute phase.

Prealbumin (also known as transthyretin) has often been used to assess the effects of protein-energy malnutrition (PEM) or any dietary on protein levels. Raguso et al. ${ }^{[22]}$ have emphasised that types of nutrition in intensive care patients may differ in prealbumin levels. Türkmen et al. ${ }^{[23]}$ used prealbumin as a biochemical marker in their study of PEM in children. However, in the same study, the findings showed that this parameter alone was not enough.

Prealbumin values may be affected by types of nutrition. Therefore, only enteral-fed patients were included in this study.

Although the prealbumin value has been used as a nutritional indicator, it has begun to be used to follow the clinical course of patients who have had major trauma in recent years. Prealbumin levels in burn patients are thought to be directly related to both the clinical course of the disease and the mortality of the patient. ${ }^{[24]}$

A study that is investigating the effects of exercise on prealbumin has not been found in the current literature. Studies on prealbumin levels in intensive care and burn patients do not include an evaluation of the efficacy of physiotherapy on prealbumin. ${ }^{[25]}$

In our study, when prealbumin levels of the treatment group were compared with the control group, there was a significant increase in the treatment group from the second week. Our findings suggest that this increase in the acute phase is very positive for the clinical course of the disease. Early physiotherapy increases both protein metabolism and decreases mortality in patients.

\section{Conclusion}

Further studies should be conducted with more patients and as a multi-centred study to provide new insights into the literature. Our findings suggest that the physiotherapy programme should be started at the earliest possible time in patients with major burn injuries. In addition to routine treatments, there must be a physiotherapy programme to reduce the effects of the hypermetabolic response due to burn injury.

\section{Conflict of interest: None declared.}

\section{REFERENCES}

1. Pazar B, İyigün E, Şahin İ. Determination of subacute and chronic period sleep quality in burn patients. [Article in Turkish]. Ulus Travma Acil Cerrahi Derg 2016;22:489-94. [CrossRef]

2. Edlich RF, Larkham N, O'Hanlan JT, Berry R, Hiebert J, Rodeheaver GT, et al. Modification of the American Burn Association injury severity grading system. JACEP 1978;7:226-8. [CrossRef]

3. Mandell SP, Gibran NS. Early Enteral Nutrition for Burn Injury. Adv Wound Care (New Rochelle) 2014;3:64-70. [CrossRef]

4. Gillenwater J, Garner W. Acute Fluid Management of Large Burns: Pathophysiology, Monitoring, and Resuscitation. Clin Plast Surg 2017;44:495-503. [CrossRef]

5. Chinese Burn Association; Chinese Association of Burn Surgeons, Cen Y, Chai J, Chen H, Chen J, Guo G, Han C, et al; Chinese Burn Care and Rehabilitation Association. Guidelines for burn rehabilitation in China. Burns Trauma 2015;3:20. [CrossRef]

6. Aguiar GC, Do Nascimento MR, De Miranda AS, Rocha NP, Teixeira AL, Scalzo PL. Effects of an exercise therapy protocol on inflammatory markers, perception of pain, and physical performance in individuals with knee osteoarthritis. Rheumatol Int 2015;35:525-31. [CrossRef]

7. Kisacik P, Unal E, Akman U, Yapali G, Karabulut E, Akdogan A. Investigating the effects of a multidimensional exercise program on symptoms and antiinflammatory status in female patients with ankylosing spondylitis. Complement Ther Clin Pract 2016;22:38-43. [CrossRef]

8. Ruiz-Castilla M, Roca O, Masclans JR, Barret JP. Recent advances in biomarkers in severe burns. Shock 2016;45:117-25. [CrossRef]

9. Portney LG, Watkins MP. Foundations of Clinical Research: Application to Practice. 3rd ed. Prentice Hall; 2009.

10. Jeschke MG, Boehning DF, Finnerty CC, Herndon DN. Effect of insulin on the inflammatory and acute phase response after burn injury. Crit Care Med 2007;35(9 Suppl):S519-23. [CrossRef]

11. Luzzani A, Polati E, Dorizzi R, Rungatscher A, Pavan R, Merlini A. Comparison of procalcitonin and $\mathrm{C}$-reactive protein as markers of sepsis. Crit Care Med 2003;31:1737-41. [CrossRef]

12. Beavers KM, Brinkley TE, Nicklas BJ. Effect of exercise training on chronic inflammation. Clin Chim Acta 2010;411:785-93. [CrossRef]

13. Lenselink EA. Role of fibronectin in normal wound healing. Int Wound J 2015;12:313-6. [CrossRef]

14. Natiella JR, Burch L, Fries KM, Upton LG, Edsberg LE. Analysis of the collagen I and fibronectin of temporomandibular joint synovial fluid and discs. J Oral Maxillofac Surg 2009;67:105-13. [CrossRef] 
15. Zhou W, Liu GH, Yang SH, Mi BB, Ye SN. Low-intensity treadmill exercise promotes rat dorsal wound healing.J Huazhong Univ Sci Technolog Med Sci 2016;36:121-6. [CrossRef]

16. Çınar MA, Bayramlar K, Erkılıç A, Güneş A, Yakut Y. Effect of early physiotherapy on fibronectin level in major burn patients: a pilot study. $\mathrm{J}$ Exerc Ther Rehabil 2017;4:105-10.

17. Deitch EA, Wheelahan TM, Rose MP, Clothier J, Cotter J. Hypertrophic burn scars: analysis of variables. J Trauma 1983;23:895-8. [CrossRef]

18. Cohen C, Leal MF, Belangero PS, Figueiredo EA, Smith MC, Andreoli $\mathrm{CV}$, et al. The roles of Tenascin $\mathrm{C}$ and Fibronectin 1 in adhesive capsulitis: a pilot gene expression study. Clinics (Sao Paulo) 2016;71:325-31.

19. Sal E, Yenicesu I, Celik N, Pasaoglu H, Celik B, Pasaoglu OT, et al. Relationship between obesity and iron deficiency anemia: is there a role of hepcidin? Hematology 2018;23:542-8. [CrossRef]

20. Pouramir M, Haghshenas O, Sorkhi H. Effects of Gymnastic Exercise on the Body Iron Status and Hematologic Profile. Iranian Journal of Medical Sciences 2014;29:140-1.
21. Beard J, Tobin B. Iron status and exercise. Am J Clin Nutr 2000;72(2 Suppl):594S-7S. [CrossRef]

22. Raguso CA, Dupertuis YM, Pichard C. The role of visceral proteins in the nutritional assessment of intensive care unit patients. Curr Opin Clin Nutr Metab Care 2003;6:211-6. [CrossRef]

23. Türkmen S, Güvenen G, Erkal S, Heral Y, Akyüz S. The serum total protein, albumin, transferrin, prealbumin and retinol-binding protein Levels in patients with protein-energy malnutrition. İstanbul Med J 1999;1:1520 .

24. Yang HT, Yim H, Cho YS, Kim D, Hur J, Kim JH, et al. Serum transthyretin level is associated with clinical severity rather than nutrition status in massively burned patients. JPEN J Parenter Enteral Nutr 2014;38:966-72. [CrossRef]

25. Yang HT, Yim H, Cho YS, Kim D, Hur J, Kim JH, et al. Prediction of clinical outcomes for massively-burned patients via serum transthyretin levels in the early postburn period. J Trauma Acute Care Surg 2012;72:999-1005. [CrossRef]

\section{ORİJINAL ÇALIŞMA - ÖZET}

\section{Majör yanıklı hastalarda erken dönem fizyoterapinin biyokimyasal parametreler üzerine etkisi: Bir yanık merkezi deneyimi \\ Dr. Murat Ali Çınar,, ${ }^{1}$ Dr. Kezban Bayramlar, ${ }^{1}$ Dr. Ahmet Erkılıç, ${ }^{2}$ Dr. Ali Güneş, ${ }^{2}$ Dr. Yavuz Yakut ${ }^{1}$}

${ }^{1}$ Hasan Kalyoncu Üniversitesi Sağıık Bilimleri Fakültesi, Fizyoterapi ve Rehabilitasyon Anabilim Dalı, Gaziantep

${ }^{2} 25$ Aralık Devlet Hastanesi, Yanık Merkezi, Genel Cerrahi Kliniği, Gaziantep

AMAÇ: Bu çalışma, majör yanıklı hastalarda erken dönem fizyoterapinin biyokimyasal parametreler üzerine etkisini araştırmak amacıyla planlandı. GEREÇ VE YÖNTEM: Çalışmaya, yaşları 2I-47 arasında değişen 10 kadın (\%50), 10 erkek (\%50) toplam 20 hasta alındı. Çalışmaya alınan hastalar, tedavi ve kontrol gurubu olmak üzere iki gruba ayrıldı. Tedavi grubundaki hastalar, hastaneye yattıkları ilk günden itibaren rutin tedavilerine (tıbbi, cerrahi vs.) ek olarak haftada dört gün olmak üzere fizyoterapi programına alındı. Fizyoterapi programı; erken mobilizasyon ve ambulasyon eğitimi, pulmoner fizyoterapi, aktif ve pasif normal eklem hareketi egzersizleri gibi parametreleri içermekteydi. Tedavi günleri salı, çarşamba, perşembe ve cuma günü olarak belirlendi. Pazartesi ameliyat günü olduğundan hastalara tedavi yapılamadı. Kontrol grubu, çeşitli nedenlerden dolayı fizyoterapi alamayan hastalardan oluşturuldu. Çalışmaya dahil edilen tüm hastaların hastaneye yatışlarından itibaren altı hafta boyunca haftalık olarak değerlendirmeleri yapıldı. Değerlendirmede demografik bilgiler, yanık hasarının özellikleri, C-reaktif protein, fibronektin, transferrin ve prealbumin gibi parametrelere bakıldı.

BULGULAR: Çalışmadan elde edilen sonuçlara bakıldığında; tüm biyokimyasal parametrelerde tedavi grubu lehine anlamlı olduğu gözlendi ( $p<0.05)$. Prealbuminde tedavi grubunda ikinci haftadan itibaren anlamlı bir yükselme görüldü $(p<0.05)$. Fibronektinde de tedavi grubunda dördüncü haftadan itibaren anlamlı bir artış gözlendi $(p<0.05)$.

TARTIŞMA: Erken fizyoterapi yanık tedavisinin önemli bir parçasıdır. Majör yanık sonrası görülen hipermetabolik cevabın etikisinin azaltılmasında, erken dönem fizyoterapinin etkili olabileceği görüşündeyiz. Ancak çok merkezli ve daha geniş çalışmalara ihtiyaç vardır.

Anahtar sözcükler: Biyokimyasal parametreler; erken fizyoterapi; fibronektin; majör yanıklar; prealbumin.

Ulus Travma Acil Cerrahi Derg 2019;25(5):46I-466 doi: 10.5505/tjtes.2018.05950 